\title{
The Challenges of Transformation: SANDF Officers' Attitudes Towards Integration, Affirmative Action, Women in Combat and Language Usage ${ }^{1}$
}

\author{
LINDY HEINEKEN \\ Centre for Military Studies, University of Stellenbosch
}

\section{Introduction}

Most countries expect their armed forces to be broadly representative of the populace with respect to race, ethnic composition, social class, religion and gender. The concern, particularly with respect to the officer corps as leaders of the armed forces, is that an unrepresentative defence force may pose a threat to the principle of civil supremacy over the military. The fact that some states are directly governed by military regimes drawn from the officer corps, while others actively strive to ensure that the armed forces remain subordinate to political control, indicates that the question of who joins the officer corps is of central importance to society. Where the armed forces do not represent the demographic composition of the populace, the minorities, or even majorities invariably regard such imbalances as inimical to their political power and safety (Baynam, 1990:9-10).

In South Africa, many years of enforced discriminatory policies has resulted in a lack of racial and gender representivity within the ranks of the former South African Defence Force (SADF). Although the racial composition of the SADF had begun to change rapidly by the late eighties, the officer corps is still mainly white. Even with the integration of the predominantly black homeland and non-statutory forces into the new South African National Defence Force (SANDF) which came into being in April 1994, the majority of leadership positions do not reflect the demographic composition of society.

The commitment of the SANDF to foster a non-racial, non-sexist and nondiscriminatory institutional culture in line with the constitutional imperatives resulted in the widespread transformation of the military affecting virtually every facet of the organisation - institutional, structural, and cultural. All standing policies and practices were subject to an intensive defence review process, with human resource issues central to the process of transformation. The first challenge was to integrate the seven different forces from vastly different military and political backgrounds, some revolutionary armies and others conventional 'professional' forces. Given the differences in standards and training, as well as the politicised nature of these integrated forces, tensions were inevitable. It was imperative that every attempt be made to foster co-operation between these former forces, not only for the military's sake, but for the security and stability of South Africa (Kynoch 1996:443).

The next challenge was to achieve representivity, but at the same time curb the loss of white expertise. As blacks were still significantly under-represented in the senior ranis, the only way to achieve this was through an active affirmative action programme. 
The immediate question was, how would this drive for representivity for the sake of legitimacy affect the competency or efficiency of the SANDF?

The establishment of a non-discriminatory institutional culture also meant the accommodation of gender equality. The sexual division of labour in the military, as in society is based on ongoing traditions concerning the 'proper' areas of labour for females and males. Previously women could only serve in non-combatant positions. The nonsexist policy of the new SANDF meant that women could no longer be barred from participating in any branch of service. As is the case elsewhere in the world, the prospect of women being allowed to serve in the frontline was met with ambivalence.

As an essentially Afrikaans institution, language was another contentious issue. Language usage is integral to the management of diversity and the SANDF had to find ways to accommodate the various language groups within its ranks. The challenge was how to strike a balance between operational requirements and the constitutional provisions on language.

The aim of this article is to discuss some of the above-mentioned challenges associated with the transformation of the SANDF, particularly those issues relating to integration, affirmative action, gender and language. This study is merely descriptive and exploratory, testing opinions of officers towards a few contentious issues at a given point of time which may benefit from future comparative analysis. As the leaders of the Defence Force, the attitudes and perceptions of officers are important as they impact on morale, cohesion and ultimately the effectiveness of the SANDF.

\section{Research design and method}

In November 1996, the Centre for Military Studies conducted a survey designed to measure the attitudes of officers towards aspects of military service. The 54 item questionnaire was distributed to junior officers studying at the Military Academy, as well as officers attending the different arms of service Junior Staff and Warfare Courses, Senior Command and Staff Courses, and Joint Staff Course. Every officer in the SANDF, is obliged to complete these courses at some stage in their career if they wish to be promoted to higher ranks (with the exception of study at the Military Academy). The value of this sample is that it provides a random cross-section of officer opinion at various strategic points in the officer's career, among all arms of service and rank groups at a specific period in time.

Everyone attending the various courses was requested to complete the questionnaire. Of the 327 responses received, 42 percent were from student officers attending the Military Academy (average rank CO-Capt), 29 percent officers attending the Junior Staff and Warfare Course (average rank Capt-Maj), 20 percent the Senior Command and Staff Course (Lt Col-Col) and eight percent the Joint Staff Course (Col-Brig) (see Table 1). The sample corresponds roughly with the broader SANDF officer population with the exception that the rank group colonel is over-represented, while women are slightly under-represented. With respect to race, the profile changed rapidly with integration, but many of these members still had to meet the requirements to be able to attend the courses. A further comment on the sample profile is that the junior officer group represents mainly officers studying at the Military Academy. As a select group their responses are not necessarily typical of officers of their equivalent rank groups, but then this group is considered to compromise the future leaders of the SANDF. 


\begin{tabular}{|l|l|c|c|}
\hline \multicolumn{2}{|c|}{ Variable } & $\begin{array}{c}\text { Sample } \\
\%\end{array}$ & $\begin{array}{c}\text { Population } \\
\%\end{array}$ \\
\hline Arm of & South African Army (SA Army) & 53 & 58 \\
Service & South African Airforce (SAAF) & 21 & 15 \\
& South African Navy (SAN) & 12 & 7 \\
& South African Medical Service & 14 & 21 \\
& (SAMS) & & \\
\hline Rank & CO- Lt-Capt & 51 & 55 \\
Group & Maj- Lt Col & 37 & 36 \\
& Col/Brig & 12 & 9 \\
\hline Race & Black (including Coloured and Asian) & 15 & 26 \\
& White & 85 & 74 \\
\hline \multirow{2}{*}{ Gender } & Male & 87 & 80 \\
& Female & 13 & 20 \\
\hline
\end{tabular}

Table 1: Comparison of sample and population profile of SANDF officers

\section{Notes for Table 1}

1 SAMS has since been renamed the South African Medical Health Services (SAMHS).

2 Statistics for broader SANDF population were obtained from Directorate Personnel Planning and are for the comparative rank group, race and gender profile as at November 1996.

3 The increase in the number of blacks in the SANDF officer population is due to integration. Many of these members were still undergoing bridging training and are thus under-represented on the various staff colleges. Most were too old to attend the Military Academy.

The non-biographic questionnaire items included attitudinal and perceptual questions that serve as institutional/occupational indicators. Many of the questions were of a general nature concerning the 'reasons for joining the defence force', to more specific questions on attitudes towards 'features of a preferred job', different 'views on aspects of military service' and whether their exists a 'need for representation' on pay and other aspects relating to their service dispensation. As this study forms part of a broader investigation conducted by the Centre for Military Studies, not all the questions included in the questionnaire are discussed in this article (Heinecken: 1997). Only those pertaining to integration, affirmative action, gender and language are discussed.

\section{Analysis of attitudes towards transformation issues}

\section{INTEGRATION OF FORMER FORCES}

The new SANDF came into being in April 1994, just after the first democratic elections. The integrated force consisted of the five statutory forces, the SADF with a full-time force strength of 85000 members, the homeland armies of the Transkei (TDF), Bophutatswana (BDF), Venda (VDF) and Ciskei (CFD) Defence Forces with a combined force strength of 10000 , and the two guerrilla non-statutory forces, the African National Congress' (ANC) Umkhonto we Sizwe (MK) with 20000 and the Pan African Congress' (PAC) Azanian People's Liberation Army (APLA), with 6000 members. Also forming part of this process, albeit later, was the incorporation of the former Kwa-Zulu Self Protection Force (KZSPF) with an estimated 1800 members (DPP, 1998). Most of the 
former homeland and non-statutory force members were integrated into the South African Army and South African Medical Health Service.

\begin{tabular}{|l|c|c|}
\cline { 2 - 3 } \multicolumn{1}{c|}{} & Percentage & Number \\
\hline Statutory Forces & $\mathbf{6 8}$ & \\
South African Defence Force & $\mathbf{4}$ & 68663 \\
Transkei Defence Force & $\mathbf{4}$ & 3768 \\
Bophutatswana Defence Force & $\mathbf{1}$ & 1264 \\
Venda Defence Force & $\mathbf{2}$ & 1716 \\
Ciskei Defence Force & $\mathbf{6}$ & 5838 \\
S A (National) Defence Force & & \\
\hline Non-Statutory Forces & $\mathbf{1 2}$ & 11826 \\
Umkhonto we Sizwe & $\mathbf{4}$ & 3735 \\
Azanian Peoples Liberation Army & $\mathbf{-}$ & 441 \\
Kwa-Zulu Self Protection Force & $\mathbf{1 0 0}$ & 101064 \\
\hline Grand Total & & \\
\hline
\end{tabular}

Table 2: Composition of SANDF by Former Force (November 1996)

\section{Notes for Table 2}

1 Members who did not belong to any former force and who joined the SANDF after April 1994.

2 Due to rounding off, figures may not add up to 100.

3 Source: Directorate Personnel Planning, SANDF Personnel Division

The process of integrating eight diverse forces has been fraught with challenges. Initially conflict arose over the pace of integration, the use of the former SADF's disciplinary code of conduct and the continued use of Afrikaans as language of instruction (Kemp, 1995:17). Former SADF members expressed their concern that the lack of conventional training of the guerrilla forces would negatively impact on the past 'high standards of professionalism'. Reports of racism were rife and many non-statutory force members complained that some officers commanding perpetuated discrimination by preaching how inferior the members of the non-statutory forces are (Weekly Mail and Guardian, 1997:6). The integration of the homeland armies was easier, since most of them were either trained in, or had instructors from the SADF. The rank structure, although inflated through rapid rank promotion, was also similar to that of the SADF.

By November 1996 two years after integration commenced, some 16002 members of the non-statutory forces were placed in posts within the SANDF. The composition of the integrated full-time force component at the time is reflected in Table 2. This composition by former force is likely to change dramatically in future. According to Matanzima, the representation per former force in the case of the SA Army, which had to absorb the greatest percentage of non-statutory force members, will be 19 percent for exMK, seven percent ex-Apla and four percent ex-KZSPF (1998:6). Former SADF members will make up a mere 30 percent of the future force structure. 


\section{ATTITUDES TOWARDS INTEGRATION}

Of the non-statutory force members integrated by 1996 some 18 percent were absorbed into the officer corps. However, as reflected in Table 1, the officer corps at the time was still overwhelmingly white and 'integration' was as much a racial issue as it was one of having to accommodate members of different military and professional backgrounds. Based on their own experiences, officers were asked to indicate whether they agreed, were unsure or disagreed with the following statement: "Integration brought about close co-operation between the former statutory and non-statutory forces".

\begin{tabular}{|l|c|c|c|c|c|c|}
\cline { 2 - 7 } \multicolumn{1}{c|}{} & \multicolumn{2}{c|}{ Agree } & \multicolumn{2}{c|}{ Unsure } & \multicolumn{2}{c|}{ Disagree } \\
\hline Arm of Service & $\%$ & $\mathrm{n}$ & $\%$ & $\mathrm{n}$ & $\%$ & $\mathrm{n}$ \\
\hline SA Army & $\mathbf{2 3}$ & 40 & $\mathbf{2 1}$ & 36 & $\mathbf{5 6}$ & 96 \\
SA Air Force & $\mathbf{1 3}$ & 9 & $\mathbf{4 3}$ & 29 & $\mathbf{4 4}$ & 30 \\
SA Navy & $\mathbf{2 1}$ & 8 & $\mathbf{4 9}$ & 19 & $\mathbf{3 1}$ & 12 \\
SA Medical Service & $\mathbf{1 3}$ & 6 & $\mathbf{2 4}$ & 11 & $\mathbf{6 3}$ & 29 \\
\hline Total & $\mathbf{1 9}$ & $\mathbf{6 3}$ & $\mathbf{2 9}$ & 95 & $\mathbf{5 1}$ & 167 \\
\hline Race & $\%$ & $\mathrm{n}$ & $\%$ & $\mathrm{n}$ & $\%$ & $\mathrm{n}$ \\
\hline Black & $\mathbf{2 6}$ & 14 & $\mathbf{4 6}$ & 25 & $\mathbf{2 9}$ & 16 \\
White & $\mathbf{1 8}$ & 48 & $\mathbf{2 6}$ & $\mathbf{6 9}$ & $\mathbf{5 6}$ & 150 \\
\hline Total & $\mathbf{1 9}$ & $\mathbf{6 2}$ & $\mathbf{2 9}$ & 94 & $\mathbf{5 2}$ & 166 \\
\hline
\end{tabular}

Table 3: Views on Integration by Arm of Service and Race

\section{Note for Table 3}

1 Statistical results for Arm of Service $n=325, p<0,00$. Race $n=322, p<0,001$.

The majority of officers ( 51 percent) disagreed that there was greater co-operation between the former non-statutory and statutory forces, 29 percent were unsure and 20 percent agreed. When the responses to the above-mentioned question were analysed by rank and gender, there was no significant difference in opinion. However, from the results in Table 3, it can be seen that a significant difference of opinion was found between the different AoS and race.

Most SAMHS and SA Army officers were of the opinion that closer co-operation between the former statutory and non-statutory forces had not taken place. The other two arms of service who were less affected by integration, were either divided or unsure. Some interesting findings emerged when views on integration were correlated by race. Two years after integration had commenced, only 18 percent of whites and 26 percent of blacks felt that there was a greater degree of co-operation between the former forces. Interestingly, just under half (46 percent) of the black (including coloured and Asian) officers, were unsure. The diverse responses of blacks also indicate that while integration has a definite racial dimension, there are other factors besides race that influence cooperation and cohesion between former statutory and non-statutory forces. 


\section{AFFIRMATIVE ACTION AND COMPETENCY}

One of the factors that continue to undermine cohesion and unity is the perception that disparities exist in levels of training and competency of members. The DoDs Equal Opportunities and Affirmative Action programmes have sought to develop the potential of members without undermining the morale of military personnel or compromising internationally accepted standards of professionalism, proficiency and safety. The approach has been that standards will not be compromised, but that those with potential must be given every opportunity to achieve those standards. Bridging and supplementary programmes have been designed to empower members, so that they are seen to stand an equal chance of demonstrating their suitability for the rank and mustering to which they aspire.

\begin{tabular}{|l|c|c|c|c|}
\cline { 2 - 5 } \multicolumn{1}{c|}{} & July 1994 & Nov 1996 & Oct 1997 & May 1998 \\
\hline Genl & - & - & - & - \\
Lt Genl & 2 & 2 & 2 & 3 \\
Maj Genl & 6 & 6 & 6 & 10 \\
Brig & 3 & 18 & 24 & 54 \\
Col & 12 & 43 & 50 & 205 \\
Lt Col & 39 & 118 & 128 & 321 \\
\hline Total & 59 & 187 & 210 & 593 \\
\hline
\end{tabular}

Table 4: Number of non-statutory force promotions by rank

\section{Note for Table 4}

1 Source: Directorate Personnel Planning, SANDF Personnel Division

To improve representivity, previously disadvantaged members with the given potential are to be 'fast-tracked' through the ranks. Fast tracking refers to the accelerated advancement of members by giving them preferential access to courses necessary for promotion and appointment to higher posts (DoD Bulletin, 1998). This will enable all members to meet the various course requirements of their particular rank group before being permanently appointed in a particular post.

As reflected in Table 4, considerable progress has been made in the past four years, particularly with the appointment of former non-statutory force promotions in the ranks Lieutenant-Colonel to Brigadier.

The problem with rapid promotion, however, is that it inevitably results in a compromise of standards of some sort or another. In the former SADF, it could take on average 18 years to reach the rank of Colonel and 28 years to attain the rank of BrigadierGeneral. The posts associated with these ranks require that incumbents not only have the necessary education, training or course qualifications, but also extensive practical experience in a variety of roles, as these command positions are responsible for the day to day management of the armed forces (Nathan, 1994:141).

Nonetheless, the political pressure to correct past racial imbalances was clear. In 1997, Deputy President Thabo Mbeki called for broad representivity at all levels within the services by 1999, giving the Defence Force a mere two years (Heitman, 1997:2). Even in the SA Army which integrated the largest number of predominantly black non- 
statutory and homeland defence force members, there is an estimated surplus of 3565 whites in the rank groups Staff Sergeant to General, but a shortage of 1599 Blacks (Matanzima, 1998: App B). Only an accelerated affirmative action programme can rectify this, but as Matanzima warned, 'representativeness is not an overnight exercise, except if you are prepared to vastly lower your standards and your operational preparedness' (1998:8). The competency and effectiveness of the SANDF could be undermined in the process.

\section{ATTITUDES TOWARDS AFFIRMATIVE ACTION}

Given the above realities, officers were asked to indicate whether they agreed, were unsure or disagreed with the statement: 'Affirmative action during the promotion of officers does not undermine the competency level of the SANDF'. The majority of officers, (79 percent) disagreed with the above statement, implying that most officers felt that affirmative action did undermine the competency and effectiveness of the SANDF. Only 12 percent thought that affirmative action did not have any impact, while 9 percent were unsure. No statistically significant relationship was found when gender or rank group was correlated with attitudes towards affirmative action. However, a significant relationship was found to exist between the dependent variable affirmative action and the independent variables AoS and race. The results are reflected in Table 5.

The results show a significant difference between the opinions of officers of the different AoS. While all four AoS were of the view that affirmative action had a detrimental impact on the competency of the SANDF, the SAMHS (89 percent); followed by the SAAF ( 85 percent) and SAN ( 82 percent) felt most strongly on this issue. The SA Army ( 74 percent) felt less so and a notable percentage (17 percent) did not consider affirmative action detrimental to competency. Sixteen percent of naval officers were unsure about the impact of affirmative action on competency.

\begin{tabular}{|l|c|c|c|c|c|c|}
\cline { 2 - 8 } \multicolumn{1}{c|}{} & \multicolumn{2}{c|}{ Agree } & \multicolumn{2}{c|}{ Unsure } & \multicolumn{2}{c|}{ Disagree } \\
\hline Arm of Service & $\%$ & $\mathrm{n}$ & $\%$ & $\mathrm{n}$ & $\%$ & $\mathrm{n}$ \\
\hline SA Army & $\mathbf{1 7}$ & 29 & $\mathbf{9}$ & 16 & $\mathbf{7 4}$ & 127 \\
SA Air Force & $\mathbf{7}$ & 5 & $\mathbf{7}$ & 5 & $\mathbf{8 5}$ & 58 \\
SA Navy & $\mathbf{2}$ & 1 & $\mathbf{1 6}$ & 6 & $\mathbf{8 2}$ & 31 \\
SA Medical Service & $\mathbf{4}$ & 2 & $\mathbf{6}$ & 3 & $\mathbf{8 9}$ & 41 \\
\hline Total & $\mathbf{1 2}$ & 37 & $\mathbf{9}$ & 30 & $\mathbf{7 9}$ & 257 \\
\hline Race & $\%$ & $\mathrm{n}$ & $\mathbf{\%}$ & $\mathrm{n}$ & $\%$ & $\mathrm{n}$ \\
\hline Black & $\mathbf{4 2}$ & 23 & $\mathbf{3 1}$ & 17 & $\mathbf{2 7}$ & 15 \\
White & $\mathbf{4 . 5}$ & 12 & $\mathbf{4 . 5}$ & 12 & $\mathbf{9 1}$ & 242 \\
\hline Total & $\mathbf{1 1}$ & 35 & $\mathbf{9}$ & 29 & $\mathbf{8 0}$ & 257 \\
\hline
\end{tabular}

Table 5: Views on Affirmative Action by Arm of Service and Race

\section{Note for Table 5}

1 Statistical results for Arm of Service $n=324, p<0,05$, Race $n=321, p<0,00$. 
With respect to race, the views of whites and blacks differ markedly on the issue of affirmative action. More than 90 percent of white officers were of the opinion that affirmative action has a negative impact on efficiency, while only 27 percent of blacks hold this view. However, almost a third ( 31 percent) of blacks were unsure about the impact of affirmative action on the competency of the SANDF.

Despite these sentiments, the realities are that in the short to medium term affirmative action is the only means by which the present racial as well as gender imbalances in the higher echelons of the SANDF can be successfully addressed.

\section{Women in combat}

In recent years, the role of women in the military has been widely debated internationally. Feminists, who have written or spoken publicly on women and military service, fall into two distinct camps. Those who oppose women's participation in any military activity (pacifist view) and those who push for the fullest possible inclusion of women in the military, including eligibility for conscription and assignment to the combat arms. This branch contends that the best way to ensure equal treatment for women is for them to share equally in the rights and duties of society (Miller 1998:37).

In South Africa, there has been a virtual dearth of debate on women in the military, feminist or other, with the exception of their possible utilisation in a combatant role. Cock maintains that the reason for this is 'the widespread acceptance of the legitimacy of the armed struggle and the notion of a just war means that the Western connection between feminism and pacifism is loosened in the South African context' (1992:12). The gender debate has focussed mainly on employment equity and the equality to rights of women in the armed forces. The issue is not the actual number of women serving in the armed forces, but the limitations placed on their employment in certain musterings.

Up until 1993, women in the SADF were excluded from training and employment in combat musterings (armour, infantry, artillery, pilots, air defence artillery, operational medical orderlies) or any other combatant role. Their functional role was limited to supportive musterings, such as finance, personnel, logistics, intelligence, medical services and welfare (Cilliers et al, 1997:6). Women were not appointed to any position that could result in close combat, direct enemy fire or positions with a substantial risk of capture, or positions of foreign exposure. This differed from the role of women in the guerrilla forces, many of whom served in combat roles (Nathan, 1994:146).

In 1994, in line with the Constitutional provisions which forbid discrimination on the grounds of race or gender, military policy guidelines were issued to allow women to be trained and employed in all ranks and positions, including combat roles. Since then, there has been a slight but steady increase in the number of women in combat positions and at decision-making levels throughout all the AoS. ${ }^{2}$ In November 1996, women in uniform made up 11 percent of the full-time force ( 8467 female out of 77432 ), by May 1998, this figure had risen to 13 percent, (9441 out of 72695), with some important senior appointments. In 1996 there were five female brigadiers and 25 female colonels. By May 1998 this figure had risen to 34 women colonels, three brigadiers and the appointment of two female major generals. Although most of the women in these senior positions are white, there are now three black women colonels, one coloured and one black major general. Of interest, is that there were virtually no black women from the former non-statutory forces or the homeland forces integrated into the senior ranks (DPD, 1998). The actual number of women in combatant positions is difficult to verify, but 
women now serve in the infantry, artillery and the armoured corps of the SA Army, as pilots and on vessels at sea (Modise: 1998).

Despite the formal provisions stipulating that women have an open career path in the military, there is still resistance to women serving in combatant positions both within the SANDF and among the general populace. In the 1996 public opinion poll omnibus survey on 'whether women should be allowed to volunteer for combat duty', 48 percent of respondents were against women serving in combatant positions, compared to 46 percent who expressed themselves in favour. Whites were by far the most supportive of women in combat roles ( 60 percent) followed by Asians ( 47 percent), blacks ( 45 percent) and coloureds ( 37 percent), with virtually no difference reported by gender (Cilliers, et al 1997:6).

\section{ATTITUDES TOWARDS WOMEN IN THE FRONTLINE}

Similar to the responses of the broader public referred to above, SANDF officers were also divided on the question of whether 'women should be allowed to do combat duty in the frontline'.

As reflected in Table 6, 48 percent of officers were against women serving in combatant roles, while 40 percent supported the view of women in the frontline. No statistically significant difference was found when the responses were correlated by rank. However, a significant relationship was found between the dependent variable women in combat and the independent variables AoS, race and gender. Most of the army and medical service officers were opposed to women serving in combat positions in the frontline. Airforce officers were clearly divided on this issue, while naval officers were markedly more supportive.

\begin{tabular}{|l|c|c|c|c|c|c|}
\cline { 2 - 7 } \multicolumn{1}{c|}{} & \multicolumn{2}{c|}{ Agree } & \multicolumn{2}{c|}{ Unsure } & \multicolumn{2}{c|}{ Disagree } \\
\hline Arm of Service & $\%$ & $\mathrm{n}$ & $\%$ & $\mathrm{n}$ & $\%$ & $\mathrm{n}$ \\
\hline SA Army & $\mathbf{3 7}$ & 63 & $\mathbf{8}$ & 14 & $\mathbf{5 5}$ & 95 \\
SA Air Force & $\mathbf{4 4}$ & 30 & $\mathbf{1 6}$ & 11 & $\mathbf{4 0}$ & 27 \\
SA Navy & $\mathbf{5 6}$ & 22 & $\mathbf{1 3}$ & 5 & $\mathbf{3 1}$ & 12 \\
SA Medical Service & $\mathbf{3 5}$ & 16 & $\mathbf{1 5}$ & $\mathbf{7}$ & $\mathbf{5 0}$ & 23 \\
Total & $\mathbf{4 0}$ & 131 & $\mathbf{1 2}$ & 37 & $\mathbf{4 8}$ & 157 \\
Race & $\%$ & $\mathrm{n}$ & $\%$ & $\mathrm{n}$ & $\%$ & $\mathrm{n}$ \\
Black & $\mathbf{4 2}$ & 23 & $\mathbf{2 2}$ & 12 & $\mathbf{3 6}$ & 20 \\
White & $\mathbf{3 9}$ & 104 & $\mathbf{9}$ & 25 & $\mathbf{5 2}$ & 137 \\
\hline Total & $\mathbf{4 0}$ & 127 & $\mathbf{1 2}$ & 37 & $\mathbf{4 8}$ & 157 \\
\hline Gender & $\%$ & $\mathrm{n}$ & $\%$ & $\mathrm{n}$ & $\%$ & $\mathrm{n}$ \\
\hline Male & $\mathbf{3 8}$ & 107 & $\mathbf{1 1}$ & 32 & $\mathbf{5 1}$ & 144 \\
Female & $\mathbf{5 7}$ & 24 & $\mathbf{1 2}$ & 5 & $\mathbf{3 1}$ & 13 \\
\hline Total & $\mathbf{4 0}$ & 131 & $\mathbf{1 2}$ & 37 & $\mathbf{4 8}$ & 157 \\
\hline
\end{tabular}

Table 6: Views on women in combat roles by arm of service and race and gender

\section{Note for Table 6}

1 Statistical results for Arm of Service $n=325, p<0,05$. Race $n=322, p<0,01$ : Gender $n=325$, $\mathrm{p}<0,05$. 
A statistically significant difference was found between the responses of white and black officers. Just over half of white SANDF officers thought that women should not serve in a combatant capacity, with 39 percent agreeing that they should be allowed to serve in the frontline. Black officers were divided on this issue, slightly more being supportive of the idea, than not, but just less than a quarter being unsure. By gender, the test of significance revealed that the views of female and male officers differed. Most female officers ( 57 percent) supported the view that women should be able to serve in combat positions, compared to only 38 percent of males.

These results illustrate that the attitudes towards whether women should be allowed to serve in combat positions in the frontline differ by AoS, race and gender.

\section{Language equity}

\section{BACKGROUND}

As with women serving in combat positions in the frontline, language usage is an equally emotive issue within the SANDF. This became evident during 1996, when the chairperson of the Parliamentary Joint Standing Committee on Defence (PJSCD) proposed that English be the operational language of the SANDF. The ensuing uproar (mainly from Afrikaans speakers) required the intervention of the President to calm emotions (Cilliers et al, 1997:12).

The (previous) language policy of the former SADF made provision for the use of the official languages, English and Afrikaans in defence correspondence on a monthly rotation basis. However in practice, most documents were (and many still are) in Afrikaans and communication, particularly in the SA Army took place in Afrikaans. The other indigenous languages were not recognised, and thus not used officially. This 'discriminatory' policy was suspended in October 1994, largely due to the Constitutional provisions on language usage. The Constitution of the RSA, Act No 108 of 1998 makes it clear that 'every person shall have the right to use the language of his or her choice' (Section 30); that 'no person shall be unfairly discriminated directly or indirectly against on the basis of, among others, language' (Section 9[3]); that each person has the right 'to receive education in the official language or languages of their choice in public educational institutions' (Section 29 [2]). In line with the Constitutional provisions, the White Paper on Defence stipulated that the DoD shall '... respect the constitutional provision on language and shall endeavour to cater for the different languages of its members. Instruction, command and control shall be conducted in a language that is commonly understood by all' 3

The DoD faces the enormous challenge of having to formulate a language policy that not only guarantees respect for home language, but ensures clear communication and accurate transfer of commands and information - a prerequisite for military operations. Two criteria were identified in selecting the official language medium for the purposes of command, control, management and training. These include 'applicability', the language best understood by the majority of the target group, and 'effectiveness'.

For the purposes of command and control, English has been identified as the official 'thread language' for defence communication. This will be supported by the use of appropriate 'link languages' (language that is dominant in a region, zone, command, formation or unit) in order to facilitate communication. For example, during Basic Training any official language understood by both the instructor and trainee may be used, but the thread language still forms the basic medium of instruction. However, from the level of Junior Staff Course and higher, instruction must be conducted in the thread 
language, although students may write their tests or assignments in the language of their choice if such an arrangement is feasible. In so doing, the DoD hopes to strike a balance between the constitutional imperatives on language and its own operational requirements.

However, equitable language treatment does not necessarily translate into equality. Besides the fact that the DoDs language policy requires a degree of thread language proficiency, many of the indigenous languages do not have the technical or tactical vocabulary used in military correspondence, training and operations (Cilliers et al, 1997:10). So while attempts are being made to accommodate the linguistic diversity within the ranks of the DoD, English is likely to, at least for the immediate future, remain the 'official' language of communication in the military.

\section{ATTITUDES TOWARDS LANGUAGE EQUITY}

Given the DoDs language policy, officers were requested to indicate 'whether they felt frustrated by the lack of respect for their home language in the SANDF'. As with the other questions, they were asked to state if they agreed, were unsure or disagreed with the above-mentioned statement.

The majority of officers (55 percent) affirmed that they experienced a lack of respect for their home language, while 32 percent indicated that they did not. Thirteen percent of respondents were unsure. When the responses of officers were correlated with rank, gender and race, the responses were evenly distributed and no statistically significant relationship was found between these variables and lack of respect for their home language. However, significant differences were found between the responses of the various AoS and language groupings, as seen in Table 7.

The arm of service that appeared by far the most frustrated with the lack of respect for home language was the SA Army, followed by the SAMHS. The SAN and SAAF were almost evenly divided on this issue, although the latter was the most uncertain. These results could perhaps be explained by the responses of officers who indicated that their home language was either one of the indigenous African languages, English or Afrikaans.

\begin{tabular}{|l|c|c|c|c|c|c|}
\cline { 2 - 7 } \multicolumn{1}{c|}{} & \multicolumn{2}{c|}{ Agree } & \multicolumn{2}{c|}{ Unsure } & \multicolumn{2}{c|}{ Disagree } \\
\hline Arm of Service & $\%$ & $\mathrm{n}$ & $\%$ & $\mathrm{n}$ & $\%$ & $\mathrm{n}$ \\
\hline SA Army & $\mathbf{6 3}$ & 107 & $\mathbf{1 1}$ & 18 & $\mathbf{2 7}$ & 46 \\
SA Air Force & $\mathbf{4 3}$ & 29 & $\mathbf{2 1}$ & 14 & $\mathbf{3 6}$ & 24 \\
SA Navy & $\mathbf{4 3}$ & 17 & $\mathbf{8}$ & 3 & $\mathbf{4 9}$ & 19 \\
SA Medical Service & $\mathbf{5 4}$ & 25 & $\mathbf{1 5}$ & $\mathbf{7}$ & $\mathbf{3 1}$ & 14 \\
\hline Total & $\mathbf{5 5}$ & 178 & $\mathbf{1 3}$ & 42 & $\mathbf{3 2}$ & 103 \\
\hline Home Language & $\%$ & $\mathrm{n}$ & $\%$ & $\mathrm{n}$ & $\%$ & $\mathrm{n}$ \\
African & $\mathbf{4 9}$ & 17 & $\mathbf{1 1}$ & 4 & $\mathbf{4 0}$ & 14 \\
English & $\mathbf{2 7}$ & 14 & $\mathbf{1 0}$ & 5 & $\mathbf{6 3}$ & 33 \\
Afrikaans & $\mathbf{6 2}$ & 144 & $\mathbf{1 4}$ & 33 & $\mathbf{2 4}$ & 55 \\
\hline Total & $\mathbf{5 5}$ & 175 & $\mathbf{1 3}$ & $\mathbf{4 2}$ & $\mathbf{3 2}$ & 102 \\
\hline
\end{tabular}

Table 7: Views on respect for home language by arm of service and language Note for Table 7

1 Statistical results for Arm of Service $n=323, p<0,05$. Home language $n=318, p<0,00$. 
Historically, Afrikaans has been and still is the lingua franca of the SA Army (the largest component of the SANDF) and as reflected in the responses of Afrikaans speakers, it is also this language group which felt most frustrated by the lack of respect for their home language. In comparison, the SAN and SAAF have always been more English oriented. As mirrored in the responses of English officers, this language group did not experience a lack of respect for their home language. Those who indicated that one of the African languages were their home language were divided, although just under half (49 percent) agreed with Afrikaans speakers that there was a lack of respect for their own language.

Thus, both black African and Afrikaans speakers experienced a lack of respect for their language and this explains why there was no significant difference when this variable was correlated with race.

\section{Discussion}

Since the integration of the former statutory and non-statutory forces into the new SANDF, both the representivity and the legitimacy of the armed forces has improved. But integration has not been an easy process. The eight armed forces eventually integrated are not only politically more conscious than most are willing to acknowledge, but also originate from vastly different military, professional and cultural backgrounds. The DoD has been faced with the challenge of having to manage the deeply entrenched ethnic and political loyalties, as well as the insecurities associated with the different levels and standards of training of these forces. Failure to manage these feelings of mistrust, insecurity and racial tensions invariably undermines effectiveness and cohesion within the armed forces.

Hence, integration has been more that an exercise in structural adaptation, or rectifying past imbalances. It is about creating a unified defence force that is legitimate in the eyes of the broader society. Yet, two and a half years after integration commenced, many officers did not feel that there was greater co-operation between former statutory and non-statutory forces. The SA Army as well as the SAMHS, which had to integrate the largest proportion of non-statutory force members felt that there was still tension between members of the former forces, while SAAF members were divided in their opinions, and the SAN felt unsure. An obvious explanation is that the SA Army and SAMHS had to integrate the largest number of non-statutory force members, while the SA Navy and SA Air Force had not experienced the impact of integration. These responses concur with findings of the British Military Advisory and Training team who recently reported that '... attitudes of some top-level management in the SA Army and SA Medical Service have hardened noticeably....' of late. If these findings are correct, it seems that subsequent to 1996 , the tensions between former forces may have worsened (Sunday Times 1998:4).

While most White officers did not feel that integration brought about greater cooperation between former statutory and non-statutory forces, the attitudes of black officers were divided, the largest percentage being unsure. The mixed responses of black officers could perhaps be ascribed to a perception among former black SADF officers that non-statutory force members are being 'advantaged' in the new SANDF, despite the fact that they were also previously 'disadvantaged' under the former dispensation. ${ }^{4}$ They are thus being disadvantaged twice, as members of these forces are given preference on military courses, which impacts on their own career advancement. 
The overarching goal of integration is to establish an institution that is professional, efficient, effective and broadly representative. Despite the integration of the predominantly Black homeland and non-statutory forces into the new SANDF, the racial and gender profile of the officer corps still does not reflect the broader demographic profile of society. The legitimacy of the armed forces is significantly influenced by this as many minorities, and even majorities, could perceive this as a potential threat to their political power and security. To ensure representivity, it is imperative that specifically black officers be advanced to higher positions within the SANDF at an accelerated pace in all occupational categories. The concern has been expressed by former SADF officers that if inexperienced persons are put into positions of authority without the necessary qualifications and experience, this will ultimately undermine the morale and competency of the SANDF (Nathan, 1994:142). However, what is often overlooked is that many of the former MK and Apla members have many years of military experience, albeit in a revolutionary army, but the value of this experience is often questioned by those who have served in the conventional 'professional' forces. Liebenberg is of the opinion that much more than professional soldiers, guerrilla or revolutionary soldiers have to rely on improvisation, creativity with often little guidance, in constantly changing political and military situations if they are to survive (1997:109). While they may lack in professional training, these abilities can introduce valuable innovations to the military organisation.

The DoDs equal opportunities and affirmative action programme has sought to encourage everyone to achieve the levels of competency required for the positions they hold. Despite this, most of the officers were of the opinion that affirmative action undermined the effectiveness of the SANDF. The SAMHS, SAAF followed by the SAN felt most strongly on this issue, while the SA Army felt less so. A possible explanation is that the medical service, navy and airforce require a higher degree of technical and professional expertise within their ranks, than the army does. The views of black and white officers also differed markedly on the issue of affirmative action, with whites feeling most strongly that affirmative action undermined the competency of the SANDF. Black officer opinion was divided. While black officers did not think that affirmative action undermined competency, almost a third were unsure. The mixed responses of black officers could possibly be ascribed to differences in opinion by former force, although this was not verified.

Affirmative action also refers to the advancement of women in decision-making and combat positions. Until 1994, women were not permitted to serve in any position that could result in close combat, direct enemy fire or positions with risk of capture. Women now constitute 13 percent of the full-time component and there has been some improvement in recent years with the appointment of women in senior decision-making positions. Yet their utilisation in combatant positions still evokes diverse emotions, both among the broader public and within the SANDF. Officers were divided on the issue of women serving in the frontline with notable differences in opinion between the different AoS, racial groups and by gender.

Within the SANDF it is especially members of the SA Army and SAMHS who were most opposed to the idea of women serving in combat positions in the frontline, while members of the SAAF were divided and members of the SAN most supportive. There may be various explanations for this. Naval and airforce officers are probably comfortable with the thought that not many women would volunteer for sea-going or (fighter) pilot positions. If they do, they would have to reach the same level of technical expertise to be appointment. Some women have already qualified as sea-going officers and pilots. The SA Army and SAMHS have more experience of the horrors of combat 
and the type of conflict the SANDF may become involved with in the region. This may have influenced their attitude towards the utilisation of women as combatants.

The majority of women officers serving in the SANDF indicated that they should be afforded the opportunity to serve in combat positions in the frontline. Should restrictions be placed on their careers, such limitations must be able to stand up in a court of law. There is no scientific proof that women are unable to handle the psychological stress of combat. Nor is there any substantial evidence that cohesion or male bonding (which is considered essential for combat effectiveness) is adversely affected by the presence of women in the military (BMSG: 1991). In fact, Harrel and Miller's research shows that 'bonding' or high social cohesion can have a deleterious effect on performance. What is more important, is a high level of task cohesion where members share a common goal and are motivated to co-ordinate their efforts as a team to achieve their goals. Gender per se, had no effect on group cohesion or task performance (1997:54).

If women meet the selection requirements and prescribed level of proficiency for a post they should be eligible for appointment. This is the policy of the SANDF. While past stereotypes may remain for some time, there is an acceptance that women have the right to choose whether they wish to serve in the frontline. The underlying principle is the 'equality of rights' of women in the armed forces. However, the question is whether this is not a double standard - to allow women to volunteer for combat duties, while it remains obligatory for men. Miller found that military women prefer the status quo if faced with the choice of compulsory duty in the combat arms (1998:34). In South Africa, this is an issue that is yet to be resolved.

The Constitution of the Republic of South Africa, not only guarantees the equality of rights of women, but also of language. South Africa has eleven different languages and all these languages must enjoy parity of esteem and be treated equitably. Also, recognising the historically diminished use and status of the indigenous languages, government departments, including the DoD, are required to elevate the status and advance the use of these languages. However, clear communication and accurate transfer of commands is a prerequisite for effective military operations. Although the DoD language policy states that it will strive to accommodate all the various language groups, English has become the language of command and control. This has led to considerable frustration within certain sectors of the SANDF. Many perceive a lack of respect for their home language, especially the predominantly Afrikaans speaking officers serving in the SA Army. The SA Army trains and fights mainly in Afrikaans, while the SA Navy and SA Airforce have traditionally been more English oriented. Officers serving in the latter AoS experienced lower levels of frustration with respect to their home language, and so too did English speaking officers. Of interest, is that almost half of the officers, who indicated that an African language was their 'mother tongue', also experienced a degree of frustration, while the remaining officers disagreed.

The DoD faces the challenge of having to balance the constitutional requirements with respect to language usage, with the practicalities of effective command and control, in such a way that it does not become an emotionally and politically divisive issue. This is indeed a challenge as within the confines of a decreasing defence budget, the DoDs ability to expand language translation and teaching services to accommodate the eleven languages, is limited. Therefore, it is presumed that English will be the lingua franca of the DoD and frustrations among Afrikaans speakers and especially among the 'indigenous' language groups may deepen in future. 


\section{Conclusion}

Certain conclusions can be reached with respect to officer opinion towards integration, affirmative action, gender and language. With the exception of women in combat positions, there were no significant differences in officer opinion by rank or gender. However, significant differences were found between the views of officers serving in the different AoS and belonging to different racial groups. In general, the opinions of SA Army and SAMHS officers are similar and both these AoS are less positive towards the impact of integration and affirmative action and the use of women in combat. The responses of SAN and SAAF officers are in general more positive although naval officers were more inclined to be unsure on some issues. The attitudes of white and black officers differed significantly, although blacks were often divided in their opinions. Concerning language usage, it is apparent that both Afrikaans and the indigenous African language groups felt frustrated by the lack of respect for their home language. This frustration was more prevalent among army and medical service officers.

These findings reveal that the SANDF is not a homogenous organisation. The diversity in opinion among officers continues to reflect the deeply entrenched racial and political sentiments often grounded in traditional stereotypes, which seem to have deepened in the years following this survey. The DoD faces the tremendous task of having to manage the diversity within its ranks and bring about greater racial, gender and language equality, without compromising its operational efficiency. This is indeed an institutional challenge and it is still unclear how official policy will be translated into practice, especially within the confines of an ever-decreasing defence budget.

\section{ENDNOTES}

1 This article is an edited version of a paper titled "Inequality and Diversity: Attitudes of SANDF officers towards integration, affirmative action, gender and language", presented at the South African Sociological Association Congress, held at Rand Afrikaans University, Johannesburg, 30 June -3 July 1998 .

2 In the past, the main motivation for allowing women to serve in the military in South Africa was the shortage of white males. Women were identified as an under-utilised source of high quality manpower. Of late, the utilisation of women centres on the increasing demand for gender equality.

The eleven official languages of the Republic of South Africa are Afrikaans, English, Ndebele, Northern Sotho, Southern Sotho, Swazi, Tsonga, Tswana, Venda, Xhosa and Zulu.

These sentiments were frequently expressed in conversations with former SADF black officers who felt that non-statutory force members nomination to military courses were given preference. The completion of military courses is linked to rank promotion and salary increase. Unfortunately, the data collected did not distinguish between statutory and non-statutory force members, although the latter were represented in the sample.

\section{BIBLIOGRAPHY}

Baynam, S. 1990. "Defence and security issues in a transitional South Africa". International Affairs Bulletin, 14 (3).

British Military Studies Group (BMSG). 1991. "Women in the Armed Forces; Britain in comparative perspective". Report by the British Military Studies Group in collaboration with the Royal Military Academy, Sandhurst, 3-4 December.

Cilliers, J., Schutte, C., Heinecken, L., Liebenberg, I., and Sass, B. 1997. "Public attitudes regarding women in the security forces and language usage in the SANDF". African Security Review, 6 (3).

Cock, J. 1992 "Feminism and militarism: Some questions raised by the Gulf War", South African Defence Review, 6.

Department of Defence. 1996. White Paper on National Defence, Pretoria.

Department of Defence Bulletin (DoD Bulletin). 1998. "A review of integration". 25 June, No 38/98. 
Directorate Personnel Planning (DPP). 1998. Statistics obtained from the SANDF Personnel Division, Pretoria, April/May.

Harrel, C. and Miller, L. 1997. New opportunities for military women: Effects upon readiness, cohesion and moral. Rand publishers, Santa Monica, Washington.

Heinecken, L. 1997. "Is selfless service becoming a misplaced service ethic? Attitudes of officers serving in the South African National Defence Force". Society in Transition, 1 (1-4).

Heitman, H.R. 1997. "South African Forces meet new challenge". Jane's CD, Ltd, JDW.

Kemp, M. 1995. "To become 1". Salut, February. Also see, De Ionno P. "The stick and carrot saves Modise's day". Sunday Times, 16 October 1994.

Kynoch, G. 1996. "The transformation of the South African Military". The Journal of Modern African Studies, 33 (1)

Liebenberg, I. 1997. "The integration of the military in post-liberation South Africa: The contribution of revolutionary armies". Armed Forces and Society, 24 (1).

Matanzima, T.T. 1998 "The changing SA Army: Human Resource Challenges". Paper delivered at The SA Army in Transition Continuity Change, Institute for Security Studies, Pretoria, 11 June 1998.

Miller, L. 1998. "Feminism and the exclusion of army women from combat". Gender Issues, Summer.

Mills, G. and Wood, G. 1993. "Ethnicity, integration and the South African armed forces", South African Defence Review, 12.

Modise, J. 1998. Address by the Minister of Defence on the occasion of the Defence Budget Vote, National Assembly, Parliament, 26 May.

Nathan, L. 1994. The Changing of the Guard. HSRC Publishers, Pretoria.

Sunday Times. 1998. "General under fire over army integration". 22 February.

Weekly Mail and Guardian. 1997. "Racism rife in new defence force". 10-16 January. 